\title{
The Changamirian offshoots in South Africa: The case of the Valoyi of Limpopo Province
}

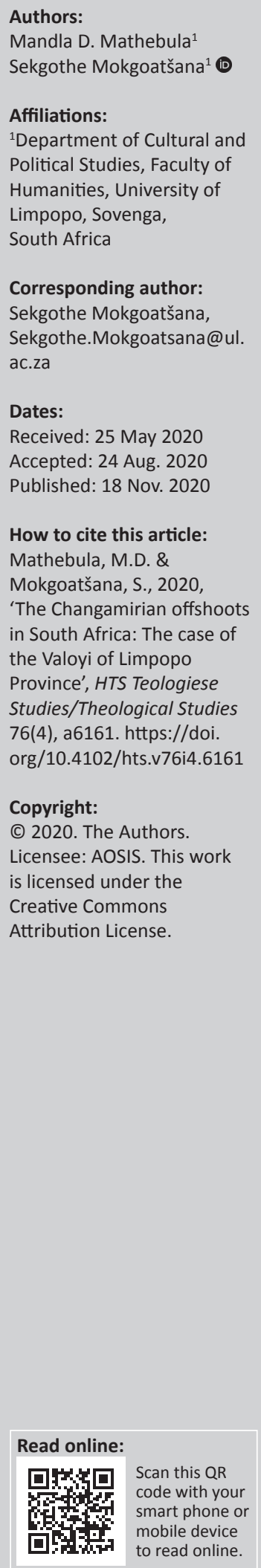

Several studies that have been conducted about the Changamire society fall short of fully explaining this ancient society's direct impact on the current Southern African ethnological landscape. Although a number of studies conducted in South Africa, Botswana, Mozambique and Zimbabwe show various societies may have emerged from the Changamire, these studies rarely give a clear chronology regarding the emigrations from this ancient society. This article uses oral historical methodology to explore the migration history and some genealogy of the Valoyi of Limpopo as one of the Changamire offshoots in an attempt to give a lucid chronology of events pertaining to one of this ancient society's traceable offshoots. Orla testimonies, conversations, anecdotes and interviews are used to collect oral data. Using oral accounts and available literature, the article outlines a movement of the Valoyi from the country of the Changamire in the present-day Zimbabwe to the present-day Mozambique and later to South Africa's Limpopo Province, where they are currently found. Following latest trends in oral history, collected data are subjected to oral historical methodology, privileging the voice of the narrator. Collected voices are triangulated with other voices and available secondary data, although there are limited written sources available. By employing oral historical methodology, the study contributes to indigenous methodologies and narrative methods of data collection and analysis, mainstreaming neglected indigenous discourses and epistemologies.

Contribution: This study broadens the debate on the role of oral history to document genealogical links within cross border historiography, especially documented fragmented communities separated by different colonial regimes.

Keywords: Changamire; emigration; Valoyi; Limpopo, chronology, Changamire offshoots.

\section{Introduction}

The ancient Changamire society, south of the Munhumutapa empire, was founded by the Changamire in 1494 as an offshoot of the Munhumutapa (Beach 1980:188; Henriksen 1978:9; Mtetwa 1984:41; Newitt 1995:102; Randles 1979:16). However, from the available evidence, it would be inaccurate to regard the first Changamire, who also reigned as a Munhumutapa between 1490 and 1494, as the founder of the Changamire society. Historical evidence suggests he lived as an integral member of the Munhumutapa. He was initially the governor of Guruuswa, one of the Munhumutapa's southern provinces, and also ruled over the area inclusive of what later became the country of the Changamire when he usurped the Munhumutapa throne in 1490 (Henriksen 1978:9; Mathebula 2018:53). Further, literature suggests the Changamire emerged as an independent society when Kakuyo Komunyaka or Chikuyo, the son of the fourth Munhumutapa ruler whom Changamire had deposed, killed Changamire in 1494. It was after this assassination that Changamire's son seceded with some of the Munhumutapa provinces to establish a separate state for the Changamire, prompting the emergence of the Changamire society (Mathebula 2018:53; Newitt 1995:102). Therefore, because Changamire cannot be regarded as the founder of the independent country of the Changamire, he also cannot be regarded as the founder of the Changamire society separate from the Munhumutapa.

To this day, scholars struggle to define the country of the Changamire, owing to scanty and often confusing historiography of the Changamire. However, sources generally agree that Changamire became the honorary title of the successive rulers of the new Changamire society (Mathebula 2018:61; Mudenge 1988:47).

From the available evidence, it seems the Changamire country centred on Guruuswa. This is so because sources suggest that Changamire first became the governor of Guruhuswa (also spelt

Note: Special Collection entitled Social Memory Studies, sub-edited by Christina Landman (UNISA) and Sekgothe Mokgoatšana (UL). 
Guruuswa or Guruwuswa) province, which was handed over to him for his outstanding services to the second Munhumutapa ruler, Matope Nyanhehwe Nebeza (Henriksen 1978:90). Several other sources say he was also in charge of the other southern province of the empire called Mbire (Henriksen 1978:9). Further, historical sources suggest that, together, these provinces constituted what became known as the Butua state later in history under the Changamire rulers (Newitt 1995:102; Randles 1979:16). However, several other sources assign the Butua state to the Torwa during the period spanning AD 1250-1685 and only associate it with the Changamire after this period (Van Waarden 2012a:4). Unfortunately, the Valoyi oral history does not define the country of the Changamire either. Nevertheless, historical evidence points to the existence of the country of the Changamire at some point in history.

Sources further suggest that the area that was under the Changamire was occupied by the people referred to as 'Borobzes' (Randles 1979:16). Due to scanty information about these people, they have been labelled as the people who have acquired a historiography without history. Often the name is associated with the people of the 17th century Changamire Dombo than other earlier Changamire rulers (Pikirai 2001:28). The Valoyi oral history suggests the existence of a Changamire succession that went on uninterrupted from the first Changamire to a man called Gulukhulu, the latter being regarded by the Valoyi as the early 17th century Changamire ruler (Mathebula 2018:63-72, 79). The oral history of the Kalanga people of Botswana, though providing a different genealogy, also concurs on the possible uninterrupted succession of Changamire rulers from the 15th century to the 19th century (Van Waarden 2012b:56-57).

The Valoyi oral history suggests Nelombe could be the founder of both the country of the Changamire and the Changamire society. The accounts seem to link him to Changamire's son, whom the 15th century Portuguese records suggest reigned from 1494 to 1547 (Jacques 1938:126; Mathebula 2018:63, 64, 72). Accordingly, the Valoyi oral history suggests that Nelombe was succeeded by his son called Chirimbi or Xirimbi, which, by implication, means the latter may have begun his reign in 1547. He, in turn, as suggested by the Valoyi oral history, was succeeded by his son called Gulukhulu, probably towards the end of the 16th century. The latter was apparently the ruler during the founding of the Valoyi as an offshoot of the Changamire (Jacques 1938:126; Mathebula 2018:71-72).

The Valoyi oral accounts mention the genealogical and political roles which Gulukhulu played in the founding of the Valoyi: firstly, as the father to the founder of the Valoyi and, secondly, as the ruler who banished the founder from his capital, after which the Valoyi as a group or society came into existence. This is also contained in the available literature, which points out that the Valoyi are the descendants of Gulukhulu (Jacques 1938:126). Other sources simply state that Gulukhulu reigned in the 'Changamire dynasty' before the breakaway of the Valoyi from the 'Changamire state' (certainly in reference to the one they founded around Guruuswa) (Mathebula 2002:96). Other sources link the name 'Gulukhulu', in its variations, with the Changamire, mainly using the variations of 'Goro' or 'Goremucuro' (Beach 1980:227; Randles 1979:16-17). Some even add the names 'Gole' and 'Gole tsangamene' (Liesegang 1977:172; Mathebula 2018:69-70). Whilst most literature only attaches these variations to the country, the Valoyi oral accounts do not attach the name 'Gulukhulu' to a country, but specifically to the ruler of the country of the Changamire, which they also call 'Vukalanga'. The accounts suggest this country was in the present-day Zimbabwe. Most importantly, the accounts also suggest 'Gulukhulu' was the name of the father of the founder of the Valoyi. This is a sharp contrast to the literature, which links the name 'Goro', 'Gole' or 'Goremucuro' specifically to the country so named (Mathebula 2018:70-74).

The Valoyi oral accounts often refer to the ancient state of the Changamire as 'Vulozwi', 'Vukalanga', 'Vunyayi' or 'Vunyayini' (Jacques 1938:63, 77-78, 127; Junod 1927:22; Mathebula 2018:71, 75). Apart from the aforementioned variations, some of the literature also refers to the country of the Changamire as 'Urozvi', 'Urobze', 'Ukalanga', 'Karanga' or 'Okalange' (Beach 1980:227; Liesegang 1977:172; Mathebula 2018:71, 81; Randles 1979:16-17). An ancient map refers to it as 'Hukaranga' (Mathebula 2018). All these names conform to the Valoyi's 'Vulozwi' and 'Vukalanga' that are dealt with earlier. Therefore, it is evident that the country of the Changamire may have been known also as 'Kalanga' and 'Lozwi', together with any other variations of the two names. The name 'Nyayi' could have also been used, albeit at a later stage (Junod 1905: 226; Mathebula 2018:82).

The Valoyi oral history suggests that the founder of the Valoyi, known as Gwambe or Gutse, was supposed to succeed Gulukhulu as the ruler of the Changamire society, but due to his expulsion, someone else succeeded Gulukhulu (Mathebula 2018:79). The name of this successor is not known in the Valoyi oral history. It is likely, though, that he was the son of Gulukhulu and probably father to Changamire Dombo and therefore brother to Gwambe. Changamire Dombo is the second prominent leader with the Changamire title after Nelombe or 'second Changamire'. Therefore, available literature generally possesses the Changamire genealogy and succession history with missing names between 1547 and the late 17th century when Changamire Dombo emerged amongst the Changamire. Unfortunately, the Valoyi oral history seems to provide names that could be featured between 1494 to the beginning of the 17th century when the Valoyi broke away from the Changamire. Thus, such names fall short to linking the 15th century Changamire and the late 17th century Changamire Dombo. Significantly, the Valoyi oral history does provide what seem to be names of the Changamire rulers during the 1st century of the existence of the Changamire society (Mathebula 2018:79-80). Recent studies amongst the Kalanga of Botswana and Zimbabwe, if further 
advanced with the studies amongst the Valoyi, provide a potential of finally filling the existing gap in the Changamire genealogy (Mathebula 2018:70-74; Van Waarden 2012b:57).

Currently, the Valoyi are concentrated in the triangle constituted by the Mabalane, Chokwe and Mapulanguene towns in Mozambique, where they have about 30 ruling lineages (Mathebula 2018:87-89, 101-103). They also have a ruling lineage in Nhlangano district in Swaziland and 20 other ruling lineages in Limpopo, in South Africa (Jacques 1938:47, 63, 77-78, 125-128; F. Baloyi, pers. comm., 10 December 2010). Those in Swaziland and Limpopo broke away from the main group in Mozambique (Junod 1905:229 241). The Limpopo group is the focus of this article, which discusses the migration of the Valoyi of Limpopo from the Changamire society. It argues that from the country of the Changamire, they went to Mozambique before crossing to Limpopo Province, where they finally settled. Consequently, it traces a migration of one of the groups formerly part of the Changamire society, thus linking one of the present-day societies with this ancient society in a more detailed manner.

\section{Emigration from the Changamire}

The exact point of departure of the Valoyi's journey to the present-day Mozambique is not available in oral accounts. All that the oral history suggests is that they came from 'Vukalanga', which is in reference to the country of the Changamire. Some of the accounts do refer to this place as 'Changamire's country'. However, because their history suggests that they came from the royal family, it could be assumed that they came from one of the capitals of the ruling lineage, with an assumption that there were several of those capitals over different periods of the existence of the state. The assumption is based on the general practice by the Kalanga rulers of the time. Portuguese sources of the 16th century state that the Kalanga rulers had various residences, which were known as Zimbabwe, spelled by earlier Portuguese writers as 'zimbaoe', 'symbaoe' or 'simbaoe', the name that was derived from a Kalanga word for 'the walled tomb of a king' (Loveday 1961:23; Mathebula 2018:81).

Some of the sources suggest that the original place of the Valoyi could be the same original place of the Changamire's main nucleus, between the Mazoe and Nyadiri rivers in the area between Manica and Torwa in the northeast of the present-day Zimbabwe towards the central part of the country (Beach 1980:227-229; Mathebula 2018:81). In this regard, therefore, the probability is that the Valoyi migrated from this area when they were expelled from the Changamire.

Few of the sources currently available are specific on the period of the founding of the Valoyi. The general expression of oral accounts is that this happened 'khale ka khaleni' [long time ago] (Mathebula 2018:85) or simply 'in very remote times' (Junod 1927:22; Mathebula 2018:86). The oral history of the Maluleke, one of the Valoyi's earliest neighbours, suggests the first half of the 17th century as the period of the founding of the group. Some of the Valoyi, too, believe they were in Mozambique around this period, apparently because of the fact that the Maluleke arrived in the district where they settled after them (Mathebula 2018:86). Based on oral accounts of the Mbhombhi, also a neighbouring society, and some literature on the Mbhombhi, there is a likelihood that they could have arrived in Mozambique in the 1630s, having arrived after the arrival of the Mbhombhi in the 1620s but before the arrival of the Maluleke around 1640 (Hedges 1978:116; Mathebula 2018:82).

Although oral history suggests that the first migration of the Valoyi was towards the present-day Mozambique, it does not explicitly explain the exact route that they took. Neither does the available literature explicitly reveal this. However, there are two perspectives on the migration of the Valoyi, which are propagated by the published sources and which provide some useful information pertaining to the route they could have taken. The perspectives are somehow related and could, in fact, be propagating the same paradigm differently.

The first perspective states that when the Valoyi migrated from their traditional country, they came through the northern part of the present-day Gaza Province in Mozambique and settled near the Indian Ocean. The perspective suggests that the Valoyi and the Maluleke, a branch of the Van'wanati, migrated together from the present-day Zimbabwe until they reached the east coast in the present-day Mozambique. As is revealed later, it is unlikely that the Valoyi and the Maluleke, or any other branch of the Van'wanati for that matter, migrated together from the present-day Zimbabwe. In fact, there is no historical evidence linking the Van'wanati, as a society, with the present-day Zimbabwe. What seems to have happened is that the Valoyi appear to have arrived in the Mozambique's interior almost at the same time with the Maluleke coming from N'wanati country in the east coast, and they settled in the vicinity of the Valoyi, who had just arrived from the present-day Zimbabwe interior. This seems to have confused some historians and made them think that when they arrived in the same district almost at the same time, they had been coming from the same place. Instead, evidence suggests the Van'wanati are of Tonga origin and occupied the Indian Ocean coast in the southeast of presentday Mozambique. When the Maluleke migrated from the east coast to the interior, they left part of the group at the coast, and those left behind retained the Van'wanati identity (Junod 1927:22; Mathebula 2018:82-83). This branch of the Van'wanati is still living along the coast to this day. It also acknowledges that the Maluleke were once part of it before they migrated into the interior, but it seems to regard itself as the real Van'wanati rather than their offshoot. Most importantly, this branch does not associate itself with present-day Zimbabwe, and its accounts refute such claims (Mathebula 2018:82-83). Instead, looking at their historical location, the Van'wanati could be associated with the Vacopi, an offshoot of the Tonga.

The second perspective suggests that the Valoyi may have migrated from the country of the Changamire and settled with the Van'wanati on the coast of the Indian Ocean in present-day Inhambane Province, from where they may have 
migrated back inland with the Maluleke (Mathebula 2018:82-83). Some of the accounts of the Valoyi suggest they were uneasy with the sea, which they described as 'the large, restless river', the kind of which they had never seen before. Therefore, they decided to migrate back to the inland (Junod 1927:22; Mathebula 2018:83). However, some oral accounts also claim it was not the entire group of the Valoyi that migrated to the coast. Instead, only part or some of the members of the group left the main group in the interior and migrated to the coast. This is the group that found the ocean in the neighbourhood unbearable and relocated to the inland. Some of them went back to the main branch, and others settled elsewhere away from the ocean (Jacques 1938:136137; Mathebula 2018:83).

An assessment of archived records from Maputo suggests that the Valoyi first occupied the area between the confluence of the Limpopo and Olifants rivers and the present-day town of Chibuto (called Ximbutsu by the locals) (Junod 1896, 1927:17; Liesegang 1977:167; Mathebula 2018:87). A similar perspective suggests that on their way from the country of the Changamire to Mozambique, the Valoyi fought with and defeated several 'Vanyayi' groups between the Limpopo and Zambezi rivers before they settled in present-day Mozambique (Junod 1927:22; Mathebula 2018:90). This conforms to the route along the northern bank of Limpopo until its confluence with the Olifants.

Both perspectives suggest that the route followed by the Valoyi (at least at some point) was to the direction of the Limpopo valley. Literature specifically states that the Valoyi have a legend that says they came down the valley of the Limpopo. The legend has it that 'they came down the valley of the Limpopo' and 'they came in such numbers that they opened out a wide track as wide as a wagon road'. Some sources describe it as: ' ... the old, old road of Gwambe, ... So well was the road trodden that to this day, the grass has not grown over it' (Junod 1927:22; Mathebula 2018:85).

Therefore, the Valoyi seem to have moved from a place between the Mazoe and Nyadiri rivers and took the southeast direction, moving along the Limpopo River on its northern bank, up to its confluence with the Olifants River. The oral history of the Valoyi, specifically for the lineages currently based in Mozambique, states that on their arrival in Mozambique, the Valoyi established a settlement north of the Limpopo River, near its confluence with the Olifants. The settlement was named 'Gulukhulu', but it was also known as 'Gutse' and later as N'wamahunyani. It was only in the later years that other settlements came up as the Valoyi expanded and consolidated (Mathebula 2018:88).

The number of people who migrated with Gwambe is not known, but the Valoyi oral history suggests they were many and they used many wagons that created a road that for years became known as 'the old road of Gwambe' (Junod 1927:22; Mathebula 2018:85). The oral history, however, creates an impression that the migration could have been a single, uninterrupted movement of people and goods, instead of a systematic movement characterised by stoppages at certain points, and splits and mergers along the way. The oral history also does not clarify how the Valoyi dealt with the groups they met on the way and their own subgroups that decided not to proceed with the main group to further destinations, if any, except the mention of wars with the 'Vanyayi'. Although the oral history generally states that this was a large group, the suggestion that they created a large road that took years to disappear is certainly an exaggeration. The suggestion that the number of people in the group that migrated to Mozambique was so large that it left the grass trodden on the way sounds like a legend. Some of the Valoyi oral accounts also create an impression that only the Gwambe family migrated, which is contradicted by the number of people they claim were involved (Mathebula 2018:85). Accounts from associated clans such as the Vombe, Ntamele and Mbhandze suggest there were a lot more people who were not members of Gwambe's family who constituted the group (Jacques 1938:73, 108, 129, 136-137; Mathebula 2002:74).

\section{The first country of the Valoyi}

The first country of the Valoyi outside the country of the Changamire was therefore in present-day Mozambique. However, the Valoyi oral history is sometimes incoherent regarding the description of the territory of the Valoyi in Mozambique and the extent of its size. For example, accounts of the Mbhandze, one of the Valoyi subgroups, and their offshoots such as the Mrori give an impression that the most eastern of these lineages, those who settled near the sea (including them), were not part of the Valoyi and therefore fell outside the Valoyi territory (Jacques 1938:73, 137; Mathebula 2018:87). The same applies to the lineages such as Xivodze (Mukansi), Xifun'wana and Mongwe, which were banished from the royal residence and eventually moved to the southwest, who give an impression that once they were banished from the royal residence, their new settlements were no longer part of the Valoyi country (Jacques 1938:77, 78, 128; Mathebula 2018:87). Yet the accounts gathered at N'wamahunyani, where the royal residence was situated, suggest that all of them occupied what still formed part of the Valoyi country and that those who settled in the east remained part of the Valoyi country, too (Mathebula 2018:87). This view is supported by the accounts of the groups that migrated into the Valoyi country in later years, which include the Dzonga and its subgroups (Mathebula 2018:89; Smith 1973:565-580).

According to the Valoyi oral history, the Gulukhulu settlement near the confluence of the Limpopo and Olifants became the capital of Gwambe, and he stayed there with many other families (Mathebula 2018:84, 88). As already pointed out, the area is currently known as N'wamahunyani, but local people also refer to it as 'Gulukhulu' and 'Gutse', the latter name confirming that this was the home to Gwambe, who also used Gutse as his name. A branch of the group settled across the Limpopo River in the south and southeast in what is 
known today as Mhangeni. There is a well-entrenched belief amongst the Valoyi oral accounts that the leader of this branch was Gwambe's brother, Xirimbi, who remained subject to Gwambe. Oral accounts obtained from the descendants of Xirimbi also support this notion. Amongst the Valoyi, this part of the country is widely referred to as 'Tiko ra ka Xirimbi' [Xirimbi's country] or 'KaXirimbi' [Xirimbi's place] (Mathebula 2018:88). The whole territory is jealously claimed by the Valoyi, who have a strong belief that they own it and its natural features and that they also named its features. For example, Erskine reports that the Valoyi were against the use of the names 'Olifants' and 'Limpopo' for the two rivers because they preferred 'Belule' (in fact, it is Balule in their oral accounts) and 'Vembe', respectively, which they believed were names that were brought about by their ancestors (Erskine 1875:78; Mathebula 2018:88-89). They also say the same about the Lebombo Mountains, which they have given the name of Longwe, which they consider to be original (Mathebula 2018:89). Oral accounts further suggest that there were several other settlements of the Valoyi across the vast territory, but most of the country remained uninhabited, which attracted many immigrant groups (especially from the south) into it in later years (Mathebula 2018:89). This concurs with the accounts gathered amongst the main of these immigrant groups (Mathebula 2018:91-94, Smith 1973:574).

The Valoyi oral history identifies only three groups that they found in the vicinity, which they also consider as their original neighbours. The first of these was in the east and is identified in the oral accounts as the 'Lenje'. Other accounts identify the same group as the Vacopi (which appears to be a recent name for the same people) and as the Lenge (which appears to be a variation of the name Lenje). The accounts also classify the Maluleke and other members of the Van'wanati as having been part of the Lenje (Mathebula 2018:89). From the look of things, the Lenje appear to have been part of the Tonga group currently based in Inhambane Province in Mozambique.

The second group was in the north, and the oral accounts simply classify it as 'Swingondzo', which is a recently invented derogatory name for the 'Vanyayi'. By all accounts, this group was part of the Kalanga group (like the Valoyi themselves). The last group was the Mbhombhi (or Maxavane) in the west between the Limpopo and Olifants rivers (regarded by the Valoyi as the most fertile and waterrich land in the district) (Mathebula 2018:90).

Later, in the further east (and east of the present-day Vanhlavi area) the Bembane came from the present-day northern KwaZulu-Natal Province of South Africa and settled there. Their new country became known as Bembane or Nkhavelana (Jacques 1938:97; Junod 1927:5; Mathebula 2018:92). The Vahlavi, also a group constituted by groups from presentday Swaziland and northern KwaZulu-Natal, settled between the Valoyi and the Bembana or Nkhavelana (Jacques 1938:62, 96-97, 100-106; Junod 1927:5; Mathebula 2018:101102). From the study conducted on the archived material from Maputo, all of which were compiled from oral accounts, it seems other immigrants that occupied parts of Valoyi country also included the Rikhotso (recorded as Loucotte) in the south and the Maluleke (indicated as Machicosse, a corruption of Maxakadzi, second ruler of the Maluleke) in the north. The Mbhombhi (Maxavane) in the west appear to have arrived there before the arrival of the Valoyi. Their country was later incorporated into that of the Valoyi (Liesegang 1977:166-167).

Evidence from the Valoyi oral history, from the genealogy and the structure of the communities currently in place (in South Africa and Mozambique), suggests that the first lineages of the Valoyi developed from the sons of Gwambe. These sons established various chiefdoms under the kingdom led by Gwambe and adopted new lineages, different from that of their father (Mathebula 2018:94-95). These chiefdoms occupied various areas of the Valoyi country and derived their names from the names of their founders (Mathebula 2018:94). There are also lineages that developed from the other houses of the Valoyi that came with Gwambe to Mozambique (whose relationships with Gwambe are not clear other than being his subjects). These include the Ntamele, Mbhandze and the Vombe (Jacques 1938:73, 108, 129; Mathebula 2018:95). However, because the migration from Mozambique to Limpopo Province involved the direct descendants of Gwambe and Xirimbi, this article does not delve into the other lineages on this matter.

\section{The Valoyi people of Limpopo}

Oral history suggests that the Valoyi of Limpopo are direct descendants of Gwambe or Gutse, his younger brother Xirimbi and their younger sister whose name is not known in the accounts. The entire oral history mentions six sons of Gwambe: Xivodze or Mukansi and Xifun'wana from the great house, Lowani from the second house, Ximbukutsu and Mpon'wa from the third house and Mpondwana from the fourth and last house. The accounts are all silent about Gwambe's wives that determine these houses (Mathebula 2018:95). Literature, however, at times confuses these sons with some of their children and grandchildren (Jacques 1938:77, 126-128; Junod 1905:229-241; Mathebula 2018:95). However, such confusion is mitigated by the consistency of the accounts of various lineages of the Valoyi on the number of sons Gwambe had and their names as well as their levels of seniority.

History suggests that Xivodze was the most senior of these sons, and he was supposed to be the heir to Gwambe's throne. Oral history also agrees that the next in line was Xifun'wana (as the second son from the great house) (Jacques 1938:126; Mathebula 2018:96). However, historical evidence suggests that Xivodze did not succeed Gwambe as the ruler of the Valoyi. The accounts (and the events that followed) suggest that his next in line, too, Xifun'wana, did not ascend the throne. The Valoyi oral history, though confirming that Xifun'wana did not rule, gives no details about the reasons for him not taking over after Xivodze could not do so (Jacques 1938:128; Mathebula 2018:97). The reason for Xivodze not 
succeeding Gwambe is undisputed in the Valoyi oral history (Mathebula 2018:97). The accounts suggest he was 'disqualified', whilst others even say he was 'banished' from the royal residence (Jacques 1938:128; Mathebula 2018:97). It is only the reasons for this 'disqualification' and/or 'banishment' upon which the oral accounts do not agree. There are two clear streams of reasoning behind his disqualification or banishment. The first stream is a very simplistic one. It is mainly recorded in the available literature. The stream suggests that Xivodze lost the right to succeed Gwambe after Gwambe made him (Xivodze) and Lowani, his other son, choose from a gombe [an object symbolising peasantry] and a xidzuvulo [an object symbolising land]. Xivodze chose the gombe, whilst Lowani chose the xidzuvulo. Thus, Gwambe then selected Lowani as his heir because the xidzuvulo represented land and land represented the power and the throne (Jacques 1938:126; Mathebula 2018:97). The second reasoning stream is widely found in the Valoyi oral history. It suggests that Xivodze either 'married' or 'impregnanted' his paternal aunt (Gwambe's sister whose name is not mentioned in the oral accounts) or both. As a measure of punishment by Gwambe and the family, Xivodze was 'disqualified' as an heir and 'banished' from the royal residence. Some oral accounts say his aunt was 'banished', too; hence, the two ended up marrying each other. In fact, oral accounts of the Xivodze suggest his mother (whose name is also unknown in the oral history) and his younger brother, Xifun'wana, were all 'banished' and the entire great house was disqualified of its status (in a manner similar to the one used by Gulukhulu to banish Gwambe and his entire house). Thus, the second house actually became the great house afterwards, paving the way for the only son in that house, Lowani, to become an heir (Jacques 1938:128; Mathebula 2018:98). Therefore, this information becomes relevant in as far as it links Xivodze's descendants in Limpopo to both Gwambe and his younger sister, through the latter's marriage to the former's son, Xivodze. Because Xirimbi's descendants are amongst the lineages of the Valoyi of Limpopo, it is safe to say the Valoyi of Limpopo are therefore the descendants of Gwambe, Xirimbi and their sister.

A similar banishment happened for the Mpondwana, after the banishment of Xivodze and the entire great house. Gwambe's granddaughter, through his son called Mpondwana, who was called N'warimbale, founded a new lineage and community that became known as Mongwe, named after her son (Jacques 1938:77-78; Mathebula 2018:98). There are three versions about the formation of the Mongwe lineage and community: The first states that N'warimbale was banished from the royal capital of the Valoyi after she fell pregnant by an unknown Nguni hunter, whose name and surname was never known; hence, Mongwe was known as 'Mongwe wa N'warimbale' [Mongwe, the son of N'warimbale] (Jacques 1938:77-78; Mathebula 2018:100). But some oral accounts of the Ntshuxi (a Mongwe lineage) suggest the man was known and although his name was not known, his surname was Ntuli, coming from present-day KwaZuluNatal (Mathebula 2018:100). The second version states that $\mathrm{N}^{\prime}$ warimbale simply left her father's homestead amongst the
Valoyi and established her own dynasty. Because of her skills in making fire and manufacturing knives, she was embraced as a leader amongst a 'Vanyayi' community that she migrated to, whilst some fled her rule (Jacques 1938:78; Mathebula 2018:100-101). The third version states that N'warimbale was married to a man called Govele who was a resident amongst the 'Vanyayi' or the Valoyi (there were apparently some still classifying the Valoyi as the Kalanga or Vanyayi) by whom she had a son called Mongwe. She is said to have left her man and brought Mongwe with her to a new area then called Mateleni, where she became the community's ruler (Jacques 1938:78; Mathebula 2018:101). Be that as it may, the Mongwe lineage developed from Mpondwana's house to be one of the prominent lineages of the Valoyi of Limpopo.

Thus, amongst the Valoyi ruling lineages of Limpopo, 19 of them are descendants of Gwambe, whilst only one descended from Xirimbi. Of those descending from Gwambe, only two are descendants of Xivodze and his aunt, whilst two others come from the Xifun'wana lineage. The Mpondwana lineage contributed three whilst the rest come from the Lowani lineage (Mathebula 2018).

\section{Migration to Limpopo}

Amongst the six lineages that developed from the sons of Gwambe, four of them, and the descendants of Xirimbi, spearheaded the Valoyi's expansion towards the west and later contributed groups that migrated to Limpopo. These were the Lowani, Xifun'wana, Xivodze and Mpondwana. One lineage comes from Xirimbi (Mathebula 2018:123-130). Oral accounts from these lineages suggest that all these lineages were located on the western part of the Valoyi country around the end of the 18th century and beginning of the 19th century and therefore bordering the Limpopo Province. This made it easy for them to 'move over' to the province when the situation demanded so (there was no border then separating Mozambique and South Africa) (Mathebula 2018:105-119). The argument is convincing, considering that evidence suggests they moved to Limpopo in various groups and in different periods (Mathebula 2018:123-130).

The Lowani group was the first to move to Limpopo towards the end of the 18th century. Whereas Lowani succeeded Gwambe and reigned from the Gulukhulu royal residence where his grave is located, a number of his descendants expanded to the west and settled mainly between the Limpopo and Olifants rivers (Mathebula 2018:123-124). They began to migrate to Limpopo in the 1790s, occupying mainly what later became known as the Kruger National Park (Mathebula 2018:124). Migrations by other lineages began in the 1830s, continuing until the middle of the 18th century, with some moving as far as the Zoutpansberg Mountains in the far northern part of Limpopo (Mathebula 2018:124-130).

\section{Conclusion}

The study of the migration history of the Valoyi provides a clearer chronology of the Valoyi's relationship with the Changamire. The Valoyi oral history and the available 
literature suggest a genealogical and political relationship between the Valoyi and the Changamire society. According to the available sources, both oral and written, the Valoyi are linked with the Changamire genealogically through the relationship between the founder of the Valoyi, Gwambe or Gutse, and one of the early 17th century rulers of the Changamire called Gulukhulu. The latter's name also appears in literature as 'Goro', 'Gole', 'Goremukuru' and 'Gore 'tsangamene'. However, literature associates these variations to the name of a country believed to have been ruled by the Changamire. On the other hand, the Valoyi oral history associates the name 'Gulukhulu' to the ruler of the Changamire country at the time of the founding of the Valoyi. Interestingly, the oral history and some of the literature suggests Gulukhulu was the father to Gwambe and his siblings, Xirimbi and his sister. It must be pointed out that the Valoyi oral history hardly remembers names of the women folk, which could be due to the status of women in the Valoyi society in ancient times. Further, historical evidence suggests the Valoyi once resided in the country of the Changamire, under the rule of the Changamire, one of whom, Gulukhulu, is known to have expelled them from that country. This adds to the political relationship they had with the Changamire.

Upon their expulsion from the country of the Changamire, the Valoyi appear to have migrated down to the south or southeast up to the vicinity of the Limpopo River, from where they seem to have followed it to the east. They settled at its confluence with the Olifants, where they established their capital north of Limpopo and several other settlements south of Limpopo after its confluence with the Olifants. They claimed the entire territory, some of which was unoccupied, up to the present-day Maluleke country in the north, the present-day Chibuto in the east, the present-day Khosa country in the south and Lebombo (also Longwe) Mountains in the west. Some of this territory was later occupied by immigrants, thus reducing significantly the Valoyi country.

Four of Gwambe's six sons are the ancestors of the Valoyi of Limpopo Province of South Africa, together with descendants of Xirimbi. In the 1790s, the first group of the Valoyi moved westwards, settling in the eastern part of Limpopo Province. Other Valoyi groups began to move into Limpopo during the period starting from the 1830s until the middle of the century. Today, there are 20 Valoyi ruling lineages in Limpopo, all of which have genealogical and political association with the Valoyi of Mozambique and the ancient Changamire society of present-day Zimbabwe.

The migration history of the Valoyi of Limpopo from the country of the Changamire to Mozambique and finally to Limpopo provides better details of one of the Changamirean emigrations. As one of the offshoots of the Changamire, the Valoyi are therefore one of the present-day societies that could be associated with one of the ancient societies of Southern Africa.

\section{Acknowledgements Competing interests}

The authors declare that they have no financial or personal relationships that may have inappropriately influenced them in writing this article.

\section{Authors' contributions}

M.D.M. and S.M. contributed to the design and implementation of the research, to the analysis of the results and to the writing of the manuscript.

\section{Funding information}

The authors received no financial support for the research, authorship or publication of this article.

\section{Data availability statement}

Data sharing is not applicable to this article, as no new data were created or analysed in this study.

\section{Disclaimer}

The views and opinions expressed in this article are those of the authors and do not necessarily reflect the official policy or position of any affiliated agency of the authors.

\section{References}

Beach, D.N., 1980, The Shona \& Zimbabwe 900-1850: An outline of Shona history, Africana Publishing Company, New York, NY.

Erskine, V., 1875, 'Journey to Umzila's, South-East Africa, in 1871-1872', Journal of Royal Geographical Society 45(1), 145-128, viewed 28 August 2015, from https:// www.jstor.org/stable/pdf/1798705.pdf?Refreqid=excelsior\%3Adad099a5667a61 9cab8f4949fcea4561.

Hedges, D.W., 1978, 'Trade and politics in southern Mozambique and Zululand in the eighteenth and early nineteenth centuries', PhD thesis, University of London.

Henriksen, T.H., 1978, Mozambique: A history, David Phillip, Cape Town.

Jacques, A.A., 1938, Swivongo swa Machangana (Vatsonga), Sasavona Publishers and Booksellers, Braamfontein.

Junod, H.A., 1896, Grammaire Ronga, Imprimerie Georges Bridel \& Cie, Lausanne.

Junod, H.A., 1905, 'The Ba-Thonga of the Transvaal (Addresses \& Papers of the British South African Association for the Advancement of Science)', South African Journal of Science 3(1), 222-262.

Junod, H.A., 1927, The life of a South African tribe, Macmillan \& Co, London.

Liesegang, G., 1977, 'New light on Venda traditions: Mahumane's account of 1730', History in Africa 4(1), 163-181. https://doi.10.2307/3171583

Loveday, A.F., 1961, Three stages of history in Rhodesia, A.A. Balkema, Cape Town.

Mathebula, M., 2002, 800 years of Tsonga history, Sharp-Shoot Publishers, Polokwane.

Mathebula, M.D., 2018, 'Genealogy and migration of the va ka Valoyi people of Limpopo province, South Africa', PhD thesis, University of Limpopo.

Mtetwa, A.H., 1984, A history of Uteve under Mwene Mutapa rulers, 1480-1834: A re-evaluation, Cambridge University Press, Cambridge.

Mudenge, S.I.G., 1988, A political history of Munhumutapa (c1400-1902), Zimbabwe Publishers, Harare.

Newitt, M., 1995, A history of Mozambique, Hurst and Company, London.

Pikirai, I., 2001, The Zimbabwe culture: Origins and decline in Southern Zambezian states, Altamira Press, New York, NY.

Randles, W.G.L., 1981, The empire of Monomotapa: From the fifteenth to the nineteenth century [L'empire du Monomotapa du XVãe au XIXe siècle, c1979] transl. R.S. Roberts, Mambo Press, Gwelo.

Smith, A.K., 1973, 'The peoples of southern Mozambique: An historical survey', Journal of African History XIV(4), 565-580. https://doi.org/10.1017/S0021853700013050

Van Waarden, C., 2012a, Butua and the end of an era: The effects of the collapse of the Kalanga state on ordinary citizens - An analysis of behaviour under stress, BAR International Series (Book 2420), British Archeology Reports, Cambridge.

Van Waarden, C., 2012b, The oral history of the Bakalanga of Botswana (Occasional Paper no.2), The Botswana Society, Gaborone. 